\title{
Quality Assessment of Human Anatomy Websites for High School Students: a Reflection in the Teaching Practice
}

\author{
Thaynan Escarião da Nóbrega ${ }^{a}$ \\ Dayanne Melquíades Pereira $\oplus^{\mathrm{b}}$ \\ Maria Katia Cordeiro da Silva $\mathbb{\circledR}^{\mathrm{b}}$ \\ Lorena de Sousa Silva ${ }^{a}$ \\ Marco Antônio Dias da Silva ${ }^{a}$ \\ Andresa Costa Pereira ${ }^{a}$ \\ ${ }^{\text {a }}$ Universidade Federal de Campina Grande, Curso de graduação em Odontologia, Unidade Acadêmica \\ de Ciências Biológicas, Patos, PB, Brasil. \\ ${ }^{\mathrm{b}}$ Escola Normal Estadual Dom Expedito E de Oliveira, Patos, PB, Brasil. \\ Received for publication on 29 Jan. 2019. Accepted, after revision, on 12 Mar. 2019. \\ Assigned editor: Renato P. dos Santos.
}

\begin{abstract}
The internet is a study tool for high school students, however, its content can be disqualified. The aim of this study was to evaluate the reliability, interactivity and use of Information and Communication Technology (ICT) by human anatomy websites focused on high school. Ten independent searches were performed on Google ${ }^{\circledR}$ using keywords related to the organic systems. Out of one hundred web links (first ten resulted from each system), only the websites containing information for high school (56\%) were analysed. Most of them had good interactivity, however, low reliability and scarcity of ICT tools. The websites "Toda Matéria" and "Só Biologia" were highly punctuated according to the previous criteria. It was concluded that the student has difficulty in finding a reliable human anatomy website focused on high school. It is important a conjunct action of teachers, school and government to improve the use of technology and enhance the Brazilian high school.
\end{abstract}

Keywords: Human Body. Human Anatomy. High School. ICT. Internet.

\section{Avaliação dos Sites de Anatomia Humana para o Ensino Médio: uma Reflexão no Ato de Ensinar}

\section{RESUMO}

A internet é ferramenta de estudo para alunos do ensino médio, entretanto seu conteúdo pode ser desqualificado. O objetivo deste trabalho foi avaliar a confiabilidade, interatividade e utilização das Tecnologias de Informação e Comunicação (TIC) por sites de anatomia humana voltados para

Corresponding author: Andresa Costa Pereira E-mail: andresa@cstr.ufcg.edu.br

\begin{tabular}{|l|l|l|l|l|l|}
\hline Acta Scientiae & Canoas & Vol. 21 & N. 4 & p.149-159 & July/Aug. 2019 \\
\hline
\end{tabular}


o ensino médio. Realizaram-se dez buscas no Google ${ }^{\circledR}$ com palavras-chave sobre os sistemas orgânicos. Dos cem sites (dez primeiros resultados de cada sistema), apenas os que continham informações para ensino médio (56\%) foram analisados. A maioria possuía boa interatividade, porém baixa confiabilidade e escassez de TIC. Os sites "Toda Matéria" e "Só Biologia" foram os mais bem pontuados quanto aos critérios propostos. Conclui-se que o aluno possui dificuldade para encontrar um site confiável sobre anatomia humana voltado para o ensino médio. Reflete-se a necessidade de uma ação conjunta de educadores, escola e governo para efetivar o uso da tecnologia e engrandecer o ensino médio brasileiro.

Palavras-chave: Corpo Humano. Anatomia Humana. Ensino Médio. TIC. Internet.

\section{INTRODUCTION}

Human anatomy is the branch of the science concerned with the body structure and organization (Dangelo \& Fattini, 2011). Its study is mandatory in all the health courses, and also as a high school biology subject (Santos, Alves, Saraiva, \& Barros, 2017).

Anatomical concepts are better understood when the human body parts can be identified through laboratory classes (Costa, Barreto, Junior, Vieira, \& Lucena, 2013). Nevertheless, the teachers face problems, including a lack of structure and didactical resources (Grimes, Rausch \& Santos, 2016). Especially in high school, it is observed that many schools do not have biology laboratories (Costa et al., 2013). A couple of outreach programs allow the high school students to have practical experiences in the laboratories of the Universities (Fonseca, 2017; Zanesco, Silva, Silva, \& Bagatini, 2017); however, these actions are sporadic and do not reach them all.

Usually, Brazilian high school students have only textbooks as an educational source for the understanding of the human body, especially those from families with low income (Beber, Pansera-de-Araújo, \& Bianchi, 2016). A single learning resource is not the best methodological approach, mainly when high school biology textbooks omit essential information or present misleading elements concerning to human body systems (Beber et al., 2016).

Consequently, the teacher has to reinvent himself/herself daily, as a mediator of teaching-learning and must be aware that the new generation of students is not satisfied with only one source of knowledge and always search for additional online content (Silva, Pereira, \& Arroio, 2017). Interactive tools such as websites, online games, virtual platforms and apps are the main option (Costa, Almeida, Nascimento \& Lopes, 2016).

The blend of traditional methods (classroom and laboratory) with online technologies characterizes blended learning. This methodology facilitates the human anatomy understanding and characterizes a more enjoyable and interactive process (Santos et al., 2017; Khalil, Abdel Meguid, \& Elkhider, 2018; Nóbrega, Ribeiro, Souto, Silva, \& Pereira, 2018). 
Despite the benefits of blended learning for education, it is hard to find reliable online content about anatomy in Brazilian higher education (Lopes, Pereira, \& Silva, 2013; Nóbrega et al., 2018). Usually, students use online engines such as Google ${ }^{\circledR}$ to search for open anatomy educational content (Phelan, Davy, O'keeffe, \& Barry, 2017; Nóbrega et al., 2018); however, the number of qualified websites is low (Marker, Juluru, Long, \& Magid, 2012; Pereira \& Dias da Silva, 2012). The scenario is worse in high school education because some students might not have the confidence to choose reliable sources for their homework.

Therefore, due to the need of researches assessing the quantity and quality of anatomical online material, this study aimed to evaluate the reliability, interactivity and effective use of Information and Communication Technologies (ICT) of human anatomy websites for high school students, using Google ${ }^{\circledR}$ as a search tool.

\section{METHODS}

Google ${ }^{\circledR}$ was used to search human anatomy websites with specific keywords (in Portuguese): "Articular system", "Circulatory system", "Digestive system", "Skeletal system", "Male genital system", "Female genital system", "Muscular System", "Nervous System", "Respiratory System" and "Urinary System".

We verified the first ten websites on each search, resulting in one hundred websites. Only those containing high school content were analyzed according to the technical criteria, the interactivity criteria and the presence of ICT.

The technical and interactivity criteria were based on the suggestion made by Pereira Neto and Paolucci (2014). The technical criteria determine the reliability of the content and consider if the website contains: 1) information about the author; 2) date of creation; and 3 ) date of the last update. The interactivity criteria verify if the website has: 1) "Contact us" or email; 2) social media associated; 3) search bar, and 4) main menu bar.

Finally, the presence of ICT can determine how the content was exposed, using different tools: 1) downloadable attachments; 2) forum and chat; 3) pictures; 4) videos and audios; 5) podcasts; 6) hypertexts; and 7) quizzes.

In order to verify the best scoring systems, the sum of the points of each website was calculated, ranging from 0 to 14: three referring to the technical criteria, four to the interactivity criteria and seven to the different ICT. We were able to determine the websites with higher, lower and average scores of each system.

For the websites found, the points of each system were calculated and the final score and average obtained. Afterwards, a ranking with the best-qualified websites was created. 


\section{RESULTS}

Out of one hundred anatomy websites, ten for each system of the human body, 56 were specific to the high school, 15 for higher education, 14 were Wikipedia ${ }^{\circledR}$ pages, 10 were YouTube $\AA$ videos and one of the websites was SlideShare $\AA$. The four repeated pages (one about the circulatory system and three about the male genital system) were excluded. The categorization of the websites according to the human systems can be observed in Figure 1.

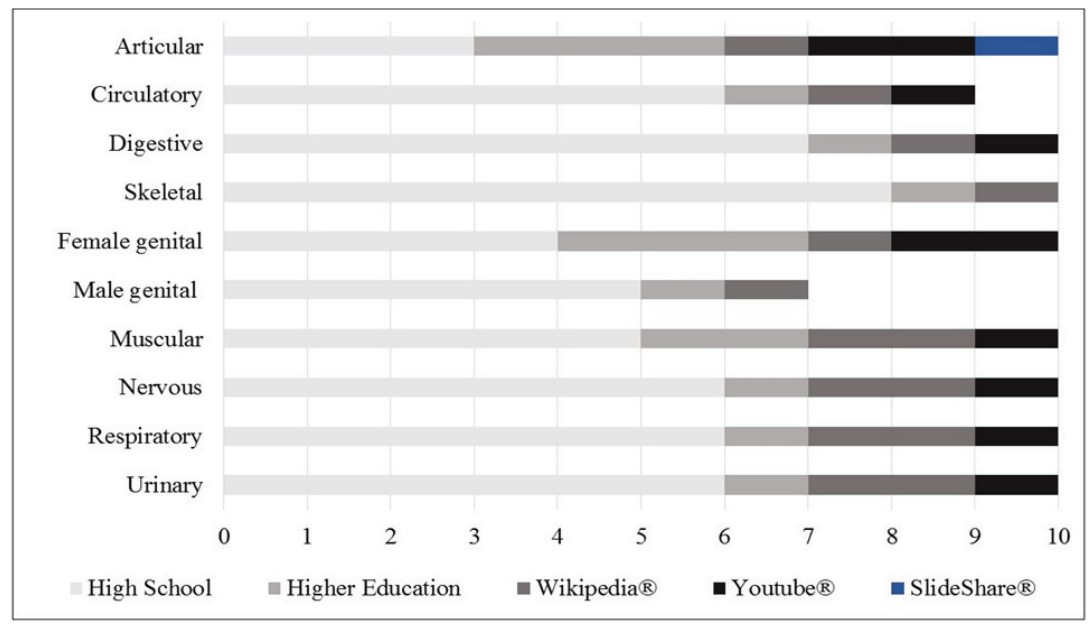

Figure 1. Categorization of websites according to each system of the human body.

Among the anatomical systems, the skeletal presented the highest number of websites (eight) for high school level, while the articular system had the worst position, with only three websites (Figure 1). None of the websites was created by a high school institution.

The 56 websites covering high school contents were analyzed according to the technical criteria, interactivity and the presence of ICT. It was observed that $46.4 \%$ of the websites displayed information about the author and 58.9\% had their creation date; however, only $14.3 \%$ specified the last update date. Half of the technical criteria was reached only by the websites about the digestive system. The articular system websites had the lowest values and had only $11.1 \%$ of the technical criteria.

Regarding the interactivity criteria, a "Contact us" link or the email of the person in charge was found in $82.1 \%$ of the websites and the social media were offered in $57.1 \%$ of the cases. There was a search bar in $94.6 \%$ of the websites and the main menu bar in $98.2 \%$. All websites presented more than $50 \%$ of the evaluated items. The websites for the circulatory system had the highest standards (95.8\%), while the articular system had the lowest $(58.3 \%)$. 
Within ICT presence, images were seen in almost all the websites (96.4\%). Forums and chats were found in $80.4 \%$, hypertext in $25 \%$, quizzes in $17.9 \%$ and downloadable attachments, such as texts, in $1.8 \%$ of the websites. Videos and audios were not found in any of the websites. Websites related to the articular system had the worst values $(14.3 \%)$, while the muscular system had the highest amount of ICT (37.1\%).

The percentages regarding reliability (based on technical criteria), interactivity and the presence of ICT in each system can be seen in Figure 2.

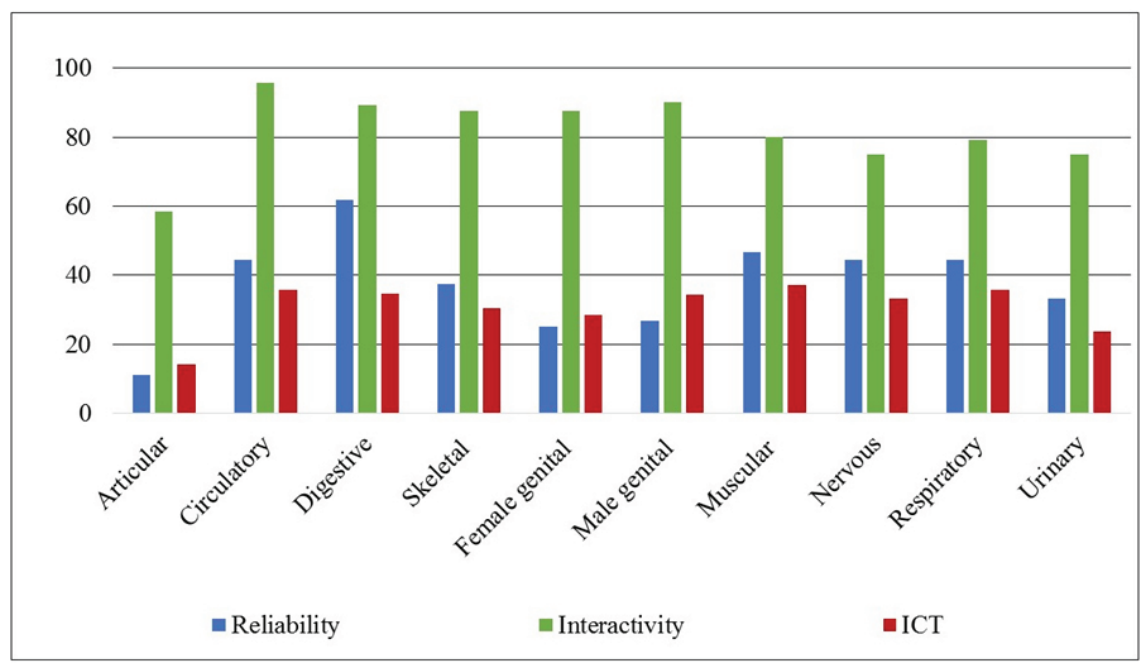

Figure 2. Percentage of reliability, interactivity and presence of ICT in each organic system.

After the sum of the technical criteria, interactivity and presence of ICT, it was possible to check the highest, the lowest and the average scores of each system (Figure 3 ), ranging from 0 to 14 points. It was noticed that the websites average scores ranged from 3.7 (articular system) to 7.9 (digestive system). The circulatory system had the highest score (10) and the articular system had the lowest (2). 


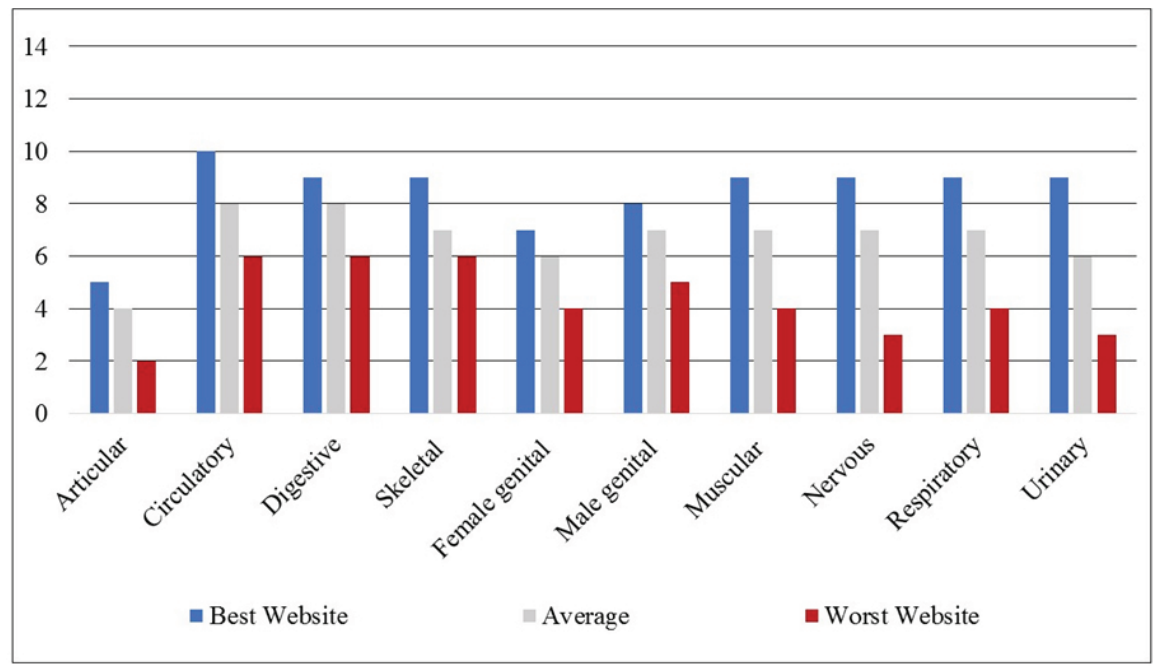

Figure 3. Absolute numbers of the best, the worst and the average scores for the websites, according to the organic system. The evaluation considered the sum of technical criteria, interactivity and the presence of ICT (scale ranging from 0-14).

Regarding the five websites most frequently found, four of them presented content for $70 \%$ of the subjects (seven of the ten systems searched) and one for $50 \%$ of the systems. After the sum of the scores of each system, the average score per subject was calculated and the ranking of the websites are shown below (Table 1).

Table 1

Ranking of the five best-evaluated websites in the research.

\begin{tabular}{|c|c|c|c|c|c|}
\hline Position & $\begin{array}{l}\text { Average score/ } \\
\text { system }\end{array}$ & $\begin{array}{l}\text { Final } \\
\text { score }\end{array}$ & $\begin{array}{l}\text { Number of } \\
\text { systems }\end{array}$ & $\begin{array}{l}\text { Name of the } \\
\text { website }\end{array}$ & $\begin{array}{l}\text { Link } \\
\text { of the website }\end{array}$ \\
\hline \multirow[t]{2}{*}{$1^{\circ}$} & 8.9 & 62 & 7 & Só Biologia & www.sobiologia.com.br \\
\hline & & & & Toda Matéria & www.todamateria.com.br \\
\hline $2^{\circ}$ & 8.6 & 43 & 5 & Info Escola & www.infoescola.com \\
\hline $3^{\circ}$ & 6.3 & 44 & 7 & Toda Biologia & www.todabiologia.com \\
\hline $4^{\circ}$ & 5.6 & 39 & 7 & Brasil Escola & https://brasilescola.uol.com.br/ \\
\hline
\end{tabular}

\section{DISCUSSION}

Brazilian high school has undergone transformations. The former passive students now search for information in a technological and active mode (Silva, Pereira \& Arroio, 2017). Students are not limited to the traditional content received in the classroom and their school-related searches are not restricted to textbooks (Nascimento \& Gasque, 2017). Teachers believe that the internet is a good tool not only to stimulate students but also 
to be used during biology classes (Grimes et al., 2016). In this context, blended learning allows the use of technologies, creates more attractive teaching and facilitates learning (Santos \& Freitas, 2017; Santos \& Leão, 2017).

The major educational concern in this new way of teaching revolves around the quality of online information. Many high school students are not trained to recognize reliable materials while searching on the internet (Nascimento \& Gasque, 2017). At the same time, teachers are unaware if online content is appropriate for their students. Due to the lack of evaluations of these virtual contents (Marker et al., 2012; Pereira \& Dias da Silva, 2012; Nóbrega et al., 2018), this was the first study to simulate an online search of human body systems performed by a high school student.

Google ${ }^{\circledR}$ was chosen because it is the most used tool by these students, who are not familiar to other sources such as virtual libraries or specific platforms for school

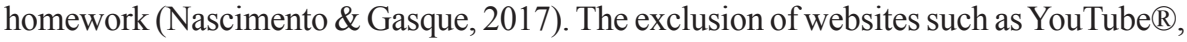
Wikipedia $\AA$ and SlideShare $\AA$ is justified to make a better standardization of the evaluation and classification criteria.

When searching for content related to human body systems, only 56 websites focused on high school. Websites dedicated to higher education were discarded once details required at the university level may confuse the high school students and prejudice their learning.

The proposal of the present research was to verify the reliability and interactivity of the website as well as its level of ICT use. It was noticed a low availability of online material for the understanding of human body systems in Brazil. Within the evaluated websites, the interactivity criteria presented higher values than the technical criteria demonstrating that the content providers care about user's interactivity, but do not give enough attention to the reliability of the material.

In the education area, scientific publications are still insufficient for this subject; therefore, the present study was based on the criteria established by health area articles, which carefully evaluated the Brazilian websites for several pathologies (Lopes, 2012; Pereira Neto, \& Paolucci, 2014; Lima, Silva, \& Pereira, 2016; Paolucci, Pereira Neto, \& Luzia, 2017).

The websites were also ranked based on the criteria. None of them reached the maximum score (Table 1); however, they are suggested to be evaluated by teachers interested in online content. The recommendation of new material benefits the student who is searching for dynamic online ways of learning (Nascimento \& Chagas, 2017; Nascimento \& Gasque, 2017). In addition, it minimizes the chance of using unreliable websites.

Teaching human body systems by creating/recommending and using websites could be a good approach to the reality of Brazilian high school. Although the use of ICT is still low in Brazilian education (Schuhmacher, Alvez Filho, \& Schuhmacher, 2017), the government has created programs that guarantee access to computers and the internet in public schools. Among them, the One Computer per Student Program (PROUCA), 
Special Regime of Acquisition of Computers for Educational use (RECOMPE) and the Broadband in Schools Program (PBLE) (Brasil, 2008; Brasil, 2010) support learning activities online.

Creating your own website also has advantages such as low cost of production and the possibility of using several ICT tools (Batista, Cavalcanti, Morais, Silva, \& Pereira, 2016). Students can have a reliable and qualified material since the teacher is the author of the website. Teachers can use texts, images, podcasts, and links for apps, YouTube $\mathbb{R}$ videos, games and social media (Facebook $\AA$ or Twitter () ) to provide their own material and/or content from external sources respecting the copyright laws.

Despite the importance of ICT as a pedagogical resource, high school teachers report a lack of technical skills with computers and low confidence in using ICT. Teachers understand that the material contributes to students' collaborative and interdisciplinary skills, but the absence of structural resources decreases the access to these tools and increases the problem (Schuhmacher et al., 2017). Perhaps these are the reasons why none of the websites found has been created by a school and its teachers.

To face these challenges, it is necessary to change the teacher's training courses and continued education regarding computational tools. In addition, it is suggested a technical team to support educators, and the spreading of positive experiences with ICT use in education (Nóbrega, Lopes, Pereira, \& Silva, 2014; Batista et al., 2016; Nóbrega, Ribeiro, Oliveira-Júnior, Pereira, \& Silva, 2018).

Although these interventions might be successful, they are long-term solutions. For now, we need faster mechanisms such as new surveys to evaluate the quality of websites. The assessment based on standard criteria can be reproduced by educators of any discipline, which can also include new parameters according to the needs of each area. The publication of similar research disseminates the information and encourages cooperative work among teachers. This strategy would reduce individual work and increase the quality of the online content available for teachers and students.

Considering human anatomy content for high school, the websites searched through Google ${ }^{\circledR}$ had good user's interaction (interactivity criteria), but low reliability (technical criteria) and minimal ICT usage. Nevertheless, it was possible to describe the best-classified websites (Table 1), which teachers can access and evaluate the quality of the content, deciding whether or not indicate it to their students.

\section{FINAL CONSIDERATIONS}

High school students have difficulties in finding a reliable website for human anatomy. It reflects the need for mutual actions among educators, school and government to implement the use of technology for the improvement of the Brazilian high school. 
In the new educational era, students search online information to complement the content delivered by teachers in the classroom. At the same time, teachers are mediators of information, responsible for the creation or at least the recommendation of reliable online material, while the students have an active role in the construction of their own learning.

We believe that some actions are required to improve the quality of Brazilian high school: (1) effective insertion of contents about the use of ICT in the pedagogical guidelines of undergraduate colleges/universities; (2) teachers' ICT qualification; (3) technical support and improvement of infrastructure; (4) evaluation of the websites and spreading of reliable content to assist teachers in using qualified material.

\section{ACKNOWLEDGEMENTS}

The present study was supported by the National Council of Scientific and Technological Development through PIBIC-EM/CNPq-UFCG Brazil program.

\section{AUTHORS' CONTRIBUTIONS STATEMENTS}

A.C.P. conceived the idea presented and supervised the project. D.M.P. and M.K.C.S. performed the activities and collected the data. All authors analyzed and discussed the results. D.M.P., M.K.C.S. and L.S.S. contributed to the initial version of the manuscript in Portuguese. T.E.N., M.A.D.S and A.C.P. contributed to the final version of the manuscript in Portuguese and English.

\section{DATA AVAILABILITY STATEMENT}

Data that support the results of this study are available as a 'supplementary file' on the Acta Scientiae website.

\section{REFERENCES}

Batista, E. P. C., Cavalcanti, M. A., Morais, R. K. A., Silva, M. A. D., \& Pereira, A. C. (2016). A internet como ferramenta extensionista. Revista Ciência em Extensão, São Paulo, 12(4), 174-182.

Beber, L. C. C., Pansera-de-Araújo, M. C., \& Bianchi, V. (2016). Sistemas digestório, respiratório e circulatório humanos em livros didáticos de biologia de ensino médio. Biografia, Bogotá, 10(18), 19-27.

Brasil. (2008). Diário Oficial da União. Decreto n. 6.424, de 4 de abril de 2008. Altera e acresce dispositivos ao Anexo do Decreto no 4.769, de 27 de junho de 2003, que aprova 
o Plano Geral de Metas para a Universalização do Serviço Telefônico Fixo Comutado prestado no Regime Público - PGMU. Diário Oficial da União, Poder Legislativo, Brasília, DF, Secção 1, p.2, 07/04/2008.

Brasil. (2010). Diário Oficial da União. Decreto n. 7.243, de 16 de julho de 2010. Regulamenta o Programa Um Computador por Aluno - PROUCA e o Regime Especial de Aquisição de Computadores para uso Educacional - RECOMPE. Diário Oficial da União, Poder Executivo, Brasília, DF, Secção 1, p.3-4, 27/07/2010.

Costa, B. D. B., Barreto, S.D., Junior, E.L.V., Vieira, G.O., \& Lucena, E.E.S. (2013). Corpo humano real e fascinante: a extensão universitária como um elo integrador entre o ensino médio/profissionalizante e o superior. Revista Extendere, Mossoró, 2(1), 36-47. Costa, R. D. A., Almeida, C. M. M., Nascimento, J. M. M., \& Lopes, P. T. C. (2016). Anato Mobile: desenvolvimento colaborativo de um sistema de aplicativos para o ensino e a aprendizagem de Anatomia Humana em cursos superiores da área da saúde. Acta Scientiae, Canoas, 18(2), 456-469.

Dangelo, J. G. \& Fattini, C. A. (2011). Anatomia Humana Sistêmica e Segmentar (3 ed.) São Paulo, Rio de Janeiro, Belo Horizonte: Atheneu.

Fonseca, J. F. C. (2017). As potencialidades de educação do projeto de extensão anatomia humana-apoio ao ensino fundamental e médio. (118f). Dissertação de mestrado, Gestão e Avaliação da Educação Pública, Faculdade de Educação/CAEd, Universidade Federal de Juiz de Fora, Juiz de Fora.

Grimes, C., Rausch, R.B., \& Santos, B. (2016). Desafios da Atuação Docente no Ensino Médio na Contemporaneidade: reflexões a partir dos dizeres de um professor de biologia. Revista Profissão Docente, Uberaba, 16(34), 42-52.

Khalil, M. K., Abdel Meguid, E. M., \& Elkhider, I. A. (2018). Teaching of anatomical sciences: A blended learning approach. Clinical Anatomy, Seattle, 31(3), 323-329.

Lima, E.S., Silva, M.A.D., \& Pereira, A.C. (2016). Confiabilidade e Qualidade das Informações On-line sobre Câncer Bucal: o Panorama Brasileiro. Revista Brasileira de Cancerologia, Rio de Janeiro, 62(2), 129-135.

Lopes, I. L. (2012). Iniciativas internacionais para o controle da qualidade da informação em Saúde na Web. Revista Eletrônica de Comunicação, Informação \& Inovação em Saúde, Rio de Janeiro, 6(2).

Lopes, R. T., Pereira, A. C., \& Silva, M. A. D. (2013). O Uso das TIC no Ensino da Morfologia nos Cursos de Saúde do Rio Grande do Norte. Revista Brasileira de Educação Médica, Rio de Janeiro, 37(3), 359-364.

Marker, D. R., Juluru K., Long C., \& Magid D. (2012). Strategic Improvements for Gross Anatomy Web-Based Teaching. Anatomy Research International, London, 12, 1-9.

Nascimento, A.M.R., \& Gasque, K.C.G.D. (2017). Novas tecnologias, a busca e o uso de informação no ensino médio. Informação \& Sociedade: Estudos, João Pessoa, 27(3), 205-218.

Nascimento, W.S. \& Chagas, R.F. (2017). O uso da internet como recurso didáticopedagógico no ensino de ciências e biologia. Revista Eletrônica de Educação da Faculdade Araguaia, Goiania, 11, 396-422.

Nóbrega, T. E., Lopes, R. T., Pereira, A. C., \& Silva, M. A. D. (2014). As TICs como ferramenta auxiliar no ensino da histologia nos cursos de Odontologia das regiões 
Nordeste e Centro-Oeste do Brasil. Revista Iberoamericana de Educación en Tecnología y Tecnología en Educación, Buenos Aires, 14, 47-54.

Nóbrega, T. E., Ribeiro, E. C., Souto, I. C. C., Silva, M. A. D., \& Pereira, A. C. (2018). Conteúdo online no ensino odontológico: análise de uma disciplina básica. Journal of Health Informatics, São Paulo, 10(2), 50-54.

Nóbrega, T. E., Ribeiro, E. C., Oliveira-Júnior, J.K., Pereira, A. C., \& Silva, M. A. D. (2018). O uso das TIC como ferramenta de ensino da histologia nos cursos de Odontologia das regiões Sul e Sudeste do Brasil. Revista Iberoamericana de Educación en Tecnología y Tecnología en Educación, Buenos Aires, 22, 63-72.

Paolucci, R., Pereira Neto, A., \& Luzia, R. (2017). Avaliação da qualidade da informação em sites de tuberculose: análise de uma experiência participativa. Saúde debate, Rio de Janeiro, 41, 84-100.

Pereira Neto, A. \& Paolucci, R. (2014). Qualidade da informação em sites de dengue: análise de uma experiência inovadora. Rio de Janeiro: ENSP/Fiocruz.

Pereira, A. C., \& Dias da Silva, M.A. (2012). Finding reliable Brazilian websites in human anatomy. In: International Conference on Education and New Learning Technologies, Barcelona. Anais do 4th International Conference on Education and New Learning Technologies.

Phelan, N., Davy, S., O’keeffe, G. W., \& Barry, D. S. (2017). Googling in anatomy education: Can google trends inform educators of national online search patterns of anatomical syllabi? Anatomical Sciences Education, Rochester, 10(2), 152-159.

Santos, R. P. \& Freitas, S. R. S. (2017). Tecnologias digitais na educação: Experiência do uso de aplicativos de celular no ensino da biologia. Cadernos de Educação, São Bernardo do Campo, 16(32), 135-150.

Santos, S. F. \& Leão, M. F. (2017). Uso de objetos educacionais digitais para ensinar sistemas do corpo humano em uma escola do campo. Revista Brasileira de Educação no Campo, Tocantinópolis, 2(3), 861-880.

Santos, S. L. F., Alves, H. H. S., Saraiva, H. S. T. T., \& Barros, K. B. N. T. (2017). Ferramentas tecnológicas aplicadas ao processo ensino-aprendizagem em anatomia humana. Revista Educação, Meio Ambiente e Saúde, Manhuaçu, 7(4), 64-72.

Schuhmacher, V. R. N., Alvez Filho, J. P., \& Schuhmacher, E. (2017). As barreiras da prática docente no uso das tecnologias de informação e comunicação. Ciência \& Educação, Bauru, 23(3), 563-576.

Silva, M. J., Pereira, M. V., \& Arroio, A. (2017). O papel do youtube no ensino de ciências para estudantes do ensino médio. Revista de Educação, Ciências e Matemática, Silva Jardim, 7(2), 35-55.

Zanesco, C., Silva, A. M., Silva, D. T. R., \& Bagatini, M. D. (2017). Ensino de anatomia humana: experiência de integração da extensão universitária com ensino médio. Revista Ciência em Extensão, São Paulo, 13(3), 127-135. 